\title{
Performance and carcass characteristics of lambs fed diets with fat and vitamin $\mathrm{E}^{1}$
}

\section{Adriana Paiva Paula Pintoㄹ, Iraides Ferreira Furusho Garcia ${ }^{3}$, Izac Leopoldino Júnior 4 , Juan Ramón Olalquiaga Pérez ${ }^{3}$, Nadja Gomes Alves $^{3}$, Idalmo Garcia Pereira ${ }^{5}$}

\author{
1 Project financed by FAPEMIG. \\ 2 Programa de Mestrado em Zootecnia - DZO - UFVJM - Diamantina. \\ 3 DZO - UFLA - Lavras. \\ ${ }^{4}$ Programa de Mestrado em Zootecnia - UFLA - Lavras. \\ ${ }^{5}$ DZO - UFVJM - Diamantina.
}

\begin{abstract}
This experiment aimed to determine the influence of diets with inclusion of protected fat and vitamin E on performance, yield and carcass characteristics of feedlot lambs with different weights. Thirty-two non-castrated Santa Ines lambs were fed diets with a ratio of $40 \%$ forage and $60 \%$ concentrate ad libitum, with presence or absence of protected fat and/or vitamin E, in a total of four diets. Two weights of early containment were also considered: between 20 and $25 \mathrm{~kg}$ and between 30 and $35 \mathrm{~kg}$. All animals were slaughtered at 84 days of confinement. Animals fed diets without addition of protected fat, regardless of the use of vitamin E, had the highest intakes of dry matter, crude protein, neutral detergent fiber and ash, and decreased intake of ether extract. The variables investigated did not affect daily weight gain and total gain. Feed conversion was better for the lighter confined animals not fed protected fat. The heavier feedlot lambs fed diets with vitamin E showed higher cold carcass. The warm carcass for the lighter animals confined fed with vitamin E, and the heavier ones, fed with protected fat and vitamin E, showed the best yields of cold carcass. Objective measures of the carcass cold had the highest mean for heavier feedlot lambs. The addition of fat in the diet reduces the intake of dry matter and increases the ether extract. Although the inclusion of vitamin has no effect on intake of nutrients, it protects the carcasses from losses during cooling, and weight differences at containment directly reflect the measures of the carcasses.
\end{abstract}

Key Words: food, lipids, nutrition, ruminants, sheep

\section{Introduction}

The sheep industry in intensive production system finds obstacles in relation to food production, which is one of the most important aspects in meat production. To achieve success in these systems, nutrient management is essential to determine existing interactions with physiological responses that alter body composition and feed conversion, with the purpose to seize the productive potential at an appropriate production cost (Carvalho \& Siqueira, 2001; Gerassev et al., 2006), and considering the quality of used ingredients (Vasconcelos, 1993; Sampaio et al., 2002). The feedlot system can reduce the production cycle and generate carcasses of young animals with better quality (Urano et al., 2006) to the market, meeting the requirements of the market for sheep meat (Perez, 2003).

According to Ribeiro (2005), lamb is the animal category of best carcass traits and, consequently, greater acceptance by consumers. According to Siqueira et al. (2001), feedlot animals must have good feed conversion, high rates of gain and adequate fat deposition.

The performance before slaughter is an important feature in choosing the right time for slaughter, along with the cost of production (Macedo et al., 2000; Pilar et al., 2003). The carcass measures characterize the product and are highly correlated with weight (Wood et al., 1980; El Karin et al., 1988), and carcasses composition, mainly by measuring the thickness of subcutaneous fat (Wood \& Macfie, 1980; Fisher, 1990).

The use of lipids in ruminant diet in confinement system can bring benefits, especially due to their high energy density with low calorie increase. However, unsaturated fatty acids can affect the rumen fermentation, and a way around this fact is the use of "protected lipids" which are not fully utilized by the microorganisms in the rumen, passing through the small intestine reducing the negative effect of fat and consequently on the degradability of fiber(Muller et al., 2005). Some experiments and studies show that the use of protected fat for meat 
production improves weight gain significantly (FurushoGarcia et al., 2010).

According to McDowell et al. (1996), the NRC (2007) recommended for ruminants, in general, from 15 to $40 \mathrm{mg} \mathrm{kg}^{-1}$ of vitamin E, but levels above therecommendation can improve performance, in addition to meat and carcass characteristics.

In this study, the objective was to evaluate performance and carcass characteristics of Santa Inês lambs using protected fat diets and vitamin E.

\section{Material and Methods}

The experiment was conducted in the Sheep sector of the Departamento de Zootecnia of the Universidade Federal de Lavras in the period of December 2009 to May 2010.

The experiment used thirty-two Santa Inês lambs with average initial age of 5 months ( $154 \pm 23.5$ days) initial body weight from 20 to $25 \mathrm{~kg}$ (average $=23.05 \mathrm{~kg} \pm 1.62$ ) and 30 to $35 \mathrm{~kg}$ (mean $=32.63 \mathrm{~kg} \pm 1.72$ ). Animals were confined in individual cages of $1.3 \mathrm{~m}^{2}$, in a shed with concrete floor, sawdust beds, individual feeders and water drinker.

The experimental period lasted 84 days and was preceded by an adaptation period of 7 days, in which lambs were fed the same diet of the experimental period. At the beginning of the adaptation period, animals were dewormed, weighed at the beginning of the experimental period and weekly until the end of the experiment, when they were weighed before and after fasting of solid food for 16 hours.

Animals were divided into eight treatments according to the experimental diet and the range of initial body weight; four animals per diet in each weight range, totaling eight lambs per diet, four of them in the live weight range of 20 to $25 \mathrm{~kg}$, and four in 30 to $35 \mathrm{~kg}$. The total diets were formulated to be isoproteic and isoenergetic with $14.5 \%$ of crude protein and $2.5 \mathrm{Mcal} / \mathrm{kg}$ of metabolizable energy to attend the nutritional requirements according to the NRC (2007) for lambs with average gains of 200 g/day (Table 1 ). The roughage:concentrate ratio was 40:60, the roughage was the "Tifton" hay and the concentrate diet was composed of corn, soybean meal, mineral and vitamin premix suitable for growing sheep and limestone. The protected fat (calcium soaps) that was used in this research is being tested in the sheep industry and is a new option for producers.

The total diet samples were collected every time a new quantity of concentrate was prepared. These samples resulted in a composite sample that was pre-dried in a forced ventilation oven at $65^{\circ} \mathrm{C}$ for 72 hours. The composite samples were ground in a mill with a sieve mesh of $1 \mathrm{~mm}$ to determine chemical composition. Bromatological analyses were performed according to Silva \& Queiroz (2002).

The diet was offered ad libitum twice daily, in the morning (8:00 $\mathrm{h})$ and in the afternoon (16:00 h), estimating a leftovers level of $20 \%$ by weighing the quantity supplied

Table 1 - Ingredients and chemical composition (\% in dry matter) of experimental diets: control (C), with vitamin E (VitE), protected fat (PF), with vitamin E and protected fat (VitEPF)

\begin{tabular}{|c|c|c|c|c|}
\hline \multirow[t]{2}{*}{ Ingredients (\%) } & \multicolumn{4}{|c|}{ Experimental diet } \\
\hline & Control & VitE & $\mathrm{PF}$ & VitEPF \\
\hline Hay & 40.0 & 40.0 & 40.0 & 40.0 \\
\hline Corn & 41.0 & 40.95 & 35.0 & 34.95 \\
\hline Soybean meal & 17.0 & 17.0 & 19.0 & 19.0 \\
\hline Vitamin E (D- $\alpha$-tocopherol) & - & 0.05 & - & 0.05 \\
\hline Protected fat & - & - & 4.0 & 4.0 \\
\hline Mineral and vitamin premix & 1.0 & 1.0 & 1.0 & 1.0 \\
\hline Limestone & 1.0 & 1.0 & 1.0 & 1.0 \\
\hline Total & 100 & 100 & 100 & 100 \\
\hline \multicolumn{5}{|l|}{ Nutrients (\%) } \\
\hline Dry matter (DM) & 95.9 & 95.6 & 95.6 & 95.4 \\
\hline Organic matter (OM) & 90.4 & 90.3 & 88.5 & 89.2 \\
\hline Crude protein $(\mathrm{CP})$ & 14.85 & 14.80 & 15.24 & 15.21 \\
\hline Neutral detergent fiber (NDF) & 40.38 & 40.36 & 39.76 & 39.75 \\
\hline Non-fiber carbohydrates ${ }^{1}$ (NFC) & 36.82 & 37.02 & 32.44 & 33.24 \\
\hline Acid detergent fiber (ADF) & 20.02 & 20.01 & 20.04 & 20.05 \\
\hline Ether extract (EE) & 2.53 & 2.51 & 5.66 & 5.62 \\
\hline Gross energy (GE) - Mcal/kg & 4.3 & 4.2 & 4.9 & 4.3 \\
\hline Hemicellulose & 20.36 & 20.33 & 19.74 & 19.72 \\
\hline Cell content & 55.52 & 55.22 & 55.84 & 55.64 \\
\hline Ash & 5.5 & 5.3 & 7.0 & 6.2 \\
\hline
\end{tabular}

${ }^{1}$ Non-fiber carbohydrates (NFC) were calculated using the formula: $\% \mathrm{NFC}=100-(\% \mathrm{CP}+\% \mathrm{EE}+\% \mathrm{NDF}+\% \mathrm{ASH})$. 
and the leftovers. Composite samples of leftovers were taken daily. These samples were submitted to laboratory analysis for determination of chemical composition, according to Silva \& Queiroz (2002), which was done by the difference between quantity supplied and quantity of nutrients in the leftovers, the determinations of dry matter intake (DMI), crude protein (CP), gross energy (GE), neutral detergent fiber (NDF), acid detergent fiber (ADF), hemicellulose and non-fiber carbohydrates.

At the end of the confinement period, and before the slaughter, animals were subjected to a 16 -hour solid fasting, weighed before and after fasting. Before the fasting period, measurements of the rib-eye area and fat thickness were taken between the $12^{\text {th }}$ and $13^{\text {th }}$ rib and at the final portion of the loin; these measurements were made by ultrasound device in the living animal. To perform this procedure, animals were shaved on the left side in the region between the $12^{\text {th }}$ and $13^{\text {th }}$ ribs and the final portion of the loin, for further implementation of the ultrasound.

After fasting, the slaughter was done with stunning by cerebral concussion and cutting the jugular veins and carotid arteries. After slaughter, full and empty digestive compartments (rumen/reticulum, omasum, abomasum, small intestine and large intestine) were removed and weighed, and the weight of gut content was obtained by the difference between full and empty compartments. Subtracting the gut content from the live weight after fasting enabled the determination of empty body weight.

After evisceration, the body parts that are not part of the carcass were removed, hot carcass weights were recorded. After 6 hours of slaughter, carcasses were cooled for a period of 24 hours in cold room with temperature ranging between 2 and $4{ }^{\circ} \mathrm{C}$, and then weighed to obtain the cold carcass weight. Thus, weight loss due to cooling could be calculated, and hot and cold carcass yields were determined relating to empty body weight.

From the whole cold carcass the following measures were recorded, according to Fisher \& Boer (1994): carcass length (distance between the base of the tail and withers); subcutaneous fat (taken between the $12^{\text {th }}$ and $13^{\text {th }}$ ribs, and the final portion of the loin), rump width (maximum width between the trochanters of both femurs), rump perimeter (perimeter of this region, referenced by the trochanters of both femurs), chest depth (maximum width between the sternum and back) and chest circumference. After that, carcasses were divided into two halves, split lengthwise. From the left half carcass, the following measures were obtained: internal length (maximum distance between the front edge of the ischium-pubic symphysis and anterior edge of the first rib), leg length (distance between the fibula and the anterior edge of the tarsal metatarsal joint) and leg width.

The trial was completely randomized in a $2 \times 2 \times 2$ factorial arrangement, two initial body weights (20 to $25 \mathrm{~kg}$ and 30 to $35 \mathrm{~kg}$ ), absence or presence of protected fat (0 and $4 \%$ in the total diet) and absence or presence of vitamin E ( 0 and $0.05 \%$ DL $\alpha$ tocopheryl acetate in the total diet). Data were analyzed with the SAS (2004) program, using the GLM procedure for analysis of variance. Means were tested using the $\mathrm{F}$ test when the interaction was not significant; otherwise, the Student $\mathrm{t}$ test, at 5 and $1 \%$ probability.

\section{Results and Discussion}

The dry matter intake relative to body weight was different for the different confinement weights. The use of protected fat in the diet influenced significantly the consumption of all nutrients. The addition of vitamin $\mathrm{E}$ in the diet did not affect the consumption of any nutrient (Table 2).

The interaction between the use of protected fat in the diet and the confinement weight affected the dry matter intake in $\mathrm{kg} /$ day and in relation to body weight (BW) in \%, and the consumption (kg/day) of neutral detergent fiber (NDF), acid detergent fiber (ADF), hemicellulose, ash, organic matter and cell content. The interaction between vitamin $\mathrm{E}$ and protected fat in the diet influenced the consumption of ether extract, organic matter and cell content. The consumption of gross energy (Mcal $/ \mathrm{kg}$ ) showed a significant difference for the interaction between the three sources of variation.

The average dry matter intake, both in $\mathrm{kg} / \mathrm{day}$ and $\%$ of live weight were different in the absence of fat for the two initial weights, the largest consumption was in the animals that began with a live weight of 20-25 kg (Table 3). Contrary to what was expected, the dry matter intake relative to body weight was higher in the lighter lambs. This can be explained by the fact that these animals probably had gone through a period of low performance due to rearing conditions before entering the experiment: lambs from twin births, with lower birth weight, or food restriction, since all animals had similar age in the beginning of the confinement. As the lambs had access to better conditions of food, increased consumption occurred when there was an offer of quality food. According to Ryan et al. (1993), increase in consumption after periods of food restriction is a mechanism that contributes to compensatory growth in sheep. For animals that started confinement in lighter weights, this gain has probably been more intense. Also for these animals, the consumption differs with fat addition, with the largest value for the 
absence of fat in the diet. On average, the dry matter intake was higher in the absence of fat in the diet. Haddad \& Younis (2004), Urano et al. (2006) and Araujo et al. (2010) also found higher dry matter intake when lipids were not included in the diet. Homem Junior (2008) and Salinas et al. (2006) did not find differences in dry matter intake when lipids were added in the diet. It is important to show that the dry matter intake for both groups of lambs, considering the final weight, was below the value suggested by NRC (2007) of 3.5\% for body weight of this category; the lighter lambs without the use of protected fat were close to this value (3.2\% of body weight).

Table 2 - Mean values of nutrient intake in dry matter, F probability for each source of variation, $\mathrm{W}=$ initial weight of confinement, $\mathrm{F}=$ presence or absence of protected fat, $\mathrm{V}=$ presence or absence of vitamin $\mathrm{E}$, their interactions and coefficient of variation $(\mathrm{CV})$

\begin{tabular}{|c|c|c|c|c|c|c|c|c|c|}
\hline \multirow[t]{3}{*}{ Variable } & \multirow[t]{3}{*}{ Mean } & \multicolumn{7}{|c|}{ F Probability } & \multirow[t]{3}{*}{$\mathrm{CV} \%$} \\
\hline & & \multirow[t]{2}{*}{ W } & \multirow[t]{2}{*}{$\mathrm{F}$} & \multirow[t]{2}{*}{$\mathrm{V}$} & \multicolumn{4}{|c|}{ Interactions } & \\
\hline & & & & & $\mathrm{W} \times \mathrm{F}$ & $\mathrm{W} \times \mathrm{V}$ & $\mathrm{F} \times \mathrm{V}$ & $\mathrm{W} \times \mathrm{F} \times \mathrm{V}$ & \\
\hline DM (kg/day) & 1.192 & 0.588 & $0.012^{*}$ & 0.766 & $0.020^{*}$ & 0.449 & 0.060 & 0.129 & 17.17 \\
\hline $\mathrm{DM}(\% \mathrm{BW})$ & 2.45 & $0.001^{* *}$ & $0.020^{*}$ & 0.739 & $0.011^{*}$ & 0.743 & 0.116 & 0.451 & 19.79 \\
\hline CP (kg/day) & 0.206 & 0.755 & $0.043^{*}$ & 0.581 & 0.060 & 0.493 & 0.060 & 0.125 & 17.46 \\
\hline EE (kg/day) & 0.052 & 0.686 & $0.0001^{* *}$ & 0.235 & 0.066 & 0.627 & $0.050^{*}$ & 0.285 & 20.31 \\
\hline NFD (kg/day) & 0.468 & 0.953 & $0.011^{*}$ & 0.964 & $0.006^{* *}$ & 0.922 & 0.206 & 0.442 & 18.33 \\
\hline ADF (kg/day) & 0.235 & 0.818 & $0.029^{*}$ & 0.911 & $0.034^{*}$ & 0.796 & 0.120 & 0.305 & 20.23 \\
\hline HEM (kg/day) & 0.224 & 0.741 & $0.018^{*}$ & 0.975 & $0.006^{* *}$ & 0.671 & 0.504 & 0.742 & 21.47 \\
\hline AS (kg/day) & 0.073 & 0.228 & $0.023^{*}$ & 0.646 & $0.037^{*}$ & 0.749 & 0.724 & 0.136 & 21.93 \\
\hline OM (kg/day) & 1.129 & 0.635 & $0.013^{*}$ & 0.723 & $0.021^{*}$ & 0.436 & $0.046^{*}$ & 0.135 & 17.20 \\
\hline GE (Mcal/kg) & 0.055 & 0.442 & $0.019^{*}$ & 0.985 & 0.064 & 0.542 & 0.339 & $0.050^{*}$ & 17.94 \\
\hline CCE (kg/day) & 0.011 & 0.354 & $0.012^{*}$ & 0.659 & $0.024^{*}$ & 0.260 & $0.047^{*}$ & 0.060 & 32.05 \\
\hline NFC (kg/day) & 0.370 & 0.131 & $0.009^{* *}$ & 0.453 & 0.433 & 0.111 & 0.060 & 0.134 & 8.35 \\
\hline
\end{tabular}

$\mathrm{DM}=$ dry matter; $\mathrm{DM}(\% \mathrm{BW})=$ dry matter in relation to body weight; $\mathrm{CP}=$ crude protein; $\mathrm{EE}=$ ether extract; $\mathrm{NDF}=$ neutral detergent fiber; ADF = acid detergent fiber; HEM = hemicellulose; AS = ashes; OM = organic matter; GE = gross energy; CCE = cell content; NFC = non-fiber carbohydrates.

* significant at $\mathrm{P}<0.05 ; * *$ significant at $\mathrm{P}<0.01$.

Table 3 - Averages for nutrients intake, depending on the unfolding of the interaction between the initial confinement weight and the presence of protected fat in diet $^{1}$

\begin{tabular}{|c|c|c|c|c|}
\hline \multirow[t]{2}{*}{ Variable } & \multirow[t]{2}{*}{ Weight } & \multicolumn{2}{|c|}{ Fat } & \multirow[t]{2}{*}{ Means } \\
\hline & & Absence & Presence (4\%) & \\
\hline \multirow[t]{3}{*}{ DM (kg/day) } & $30-35 \mathrm{~kg}$ & $1.198 \mathrm{Ab}$ & $1.193 \mathrm{Aa}$ & $1.190 \mathrm{a}$ \\
\hline & $20-25 \mathrm{~kg}$ & $1.422 \mathrm{Aa}$ & $1.040 \mathrm{Ba}$ & $1.231 \mathrm{a}$ \\
\hline & Means & $1.310 \mathrm{~A}$ & $1.111 \mathrm{~B}$ & $\mathrm{CV}=17.17 \%$ \\
\hline \multirow[t]{3}{*}{ DM (\% of BW) } & $30-35 \mathrm{~kg}$ & $2.15 \mathrm{Ab}$ & $2.20 \mathrm{Aa}$ & $2.18 b$ \\
\hline & $20-25 \mathrm{~kg}$ & $3.26 \mathrm{Aa}$ & $2.35 \mathrm{Ba}$ & $2.81 \mathrm{a}$ \\
\hline & Means & $2.71 \mathrm{~A}$ & $2.28 \mathrm{~B}$ & $\mathrm{CV}=19.79 \%$ \\
\hline \multirow[t]{3}{*}{ NDF (kg/day) } & $30-35 \mathrm{~kg}$ & $0.463 \mathrm{Ab}$ & $0.470 \mathrm{Aa}$ & $0.466 \mathrm{a}$ \\
\hline & $20-25 \mathrm{~kg}$ & $0.551 \mathrm{Aa}$ & $0.378 \mathrm{Bb}$ & $0.465 \mathrm{a}$ \\
\hline & Means & $0.517 \mathrm{~A}$ & $0.424 \mathrm{~B}$ & $\mathrm{CV}=18.33 \%$ \\
\hline \multirow[t]{3}{*}{ ADF (kg/day) } & $30-35 \mathrm{~kg}$ & $0.237 \mathrm{Aa}$ & $0.235 \mathrm{Aa}$ & $0.236 \mathrm{a}$ \\
\hline & $20-25 \mathrm{~kg}$ & $0.279 \mathrm{Aa}$ & $0.201 \mathrm{Ba}$ & $0.240 \mathrm{a}$ \\
\hline & Means & $0.268 \mathrm{~A}$ & $0.228 \mathrm{~B}$ & $C V=20.23 \%$ \\
\hline \multirow[t]{3}{*}{ Hemicellulose (kg/day) } & $30-35 \mathrm{~kg}$ & $0.226 \mathrm{Aa}$ & $0.234 \mathrm{Aa}$ & $0.230 \mathrm{a}$ \\
\hline & $20-25 \mathrm{~kg}$ & $0.272 \mathrm{Aa}$ & $0.176 \mathrm{Bb}$ & $0.224 a$ \\
\hline & Means & $0.249 \mathrm{~A}$ & $0.205 B$ & $C V=21.47 \%$ \\
\hline \multirow[t]{3}{*}{ Ashes (kg/day) } & $30-35 \mathrm{~kg}$ & $0.071 \mathrm{Ab}$ & $0.070 \mathrm{Aa}$ & $0.070 \mathrm{a}$ \\
\hline & $20-25 \mathrm{~kg}$ & $0.091 \mathrm{Aa}$ & $0.064 \mathrm{Ba}$ & $0.077 \mathrm{a}$ \\
\hline & Means & $0.081 \mathrm{~A}$ & $0.067 \mathrm{~B}$ & $C V=21.93 \%$ \\
\hline \multirow[t]{3}{*}{ Organic matter (kg/day) } & $30-35 \mathrm{~kg}$ & $1.127 \mathrm{Ab}$ & $1.113 \mathrm{Aa}$ & $1.120 \mathrm{a}$ \\
\hline & $20-25 \mathrm{~kg}$ & $1.331 \mathrm{Aa}$ & $0.975 \mathrm{Ba}$ & 1.153a \\
\hline & Means & $1.229 \mathrm{~A}$ & $1.044 \mathrm{~B}$ & $\mathrm{CV}=17.20 \%$ \\
\hline \multirow[t]{3}{*}{ Cellular content (kg/day) } & $30-35 \mathrm{~kg}$ & $0.011 \mathrm{Ab}$ & $0.010 \mathrm{Aa}$ & $0.011 \mathrm{a}$ \\
\hline & $20-25 \mathrm{~kg}$ & $0.015 \mathrm{Aa}$ & $0.009 \mathrm{Ba}$ & $0.012 \mathrm{a}$ \\
\hline & Means & $0.013 \mathrm{~A}$ & $0.010 \mathrm{~B}$ & $\mathrm{CV}=32.05 \%$ \\
\hline
\end{tabular}

${ }^{1}$ Means followed by different letters, uppercase in rows and lowercase in columns, differ by t test. DM = dry matter; $\mathrm{BW}=$ dry matter in relation to body weight, NDF = neutra detergent fiber, ADF = acid detergent fiber.

$\mathrm{CV}=$ coefficient of variation. 
According to Van Soest (1994), consumption increases with the development of the animal body, due to the increasing capacity of daily intake of dry matter. Probably, the reduction in dry matter intake for the treatments with the addition of protected fat observed in this study was due to higher energy content caused by the addition of lipid in the diet, limiting the dry matter intake, since fat contains more than the double of the energy compared with carbohydrates.

The NDF intake (kg/day) differed significantly in the absence of fat for the different weights, having the highest average in the weight range of $20-25 \mathrm{~kg}$ (Table 3). The average intake for this nutrient also differed in the range of 20-25 kg for the addition of fat, and the absence of fat in the diet gave the highest average. In the presence of fat, the lambs weighing $30-35 \mathrm{~kg}$ consumed larger amounts of NDF. In the overall averages, there was no difference in the confinement weights, but there was difference for use of protected fat in the diet; NDF intake was higher in the absence of fat. Homem Junior (2008), studying the inclusion of lipids from sunflower seeds or from the protected fat in high concentrate diets for lambs, did not observe differences for the consumption of neutral detergent fiber.

The consumption of hemicellulose in the presence of protected fat in the diet was higher for the confined animals with higher weight (Table 3). For animals confined with $20-25 \mathrm{~kg}$ the consumption was higher in the absence of fat. The dry matter intake of lambs confined with a lower weight range was higher when there was no fat in the diet (Table 3), so the consumption of all other nutrients, including hemicellulose was greater under these conditions. The consumption of ash and organic matter (Table 3) and the initial weight of 20-25 kg resulted in higher mean in the absence of dietary fat when compared with the initial weight of $30-35 \mathrm{~kg}$. The lambs with initial confinement weight of $20-25 \mathrm{~kg}$ had the highest consumption in the absence of dietary fat in relation to the presence of protected fat in the diet. The consumption of cellular content (Table 3) in the diet without fat was greater for animals with lower weight. Considering only the confined animals with lower weight, the consumption of cellular content was higher in the diet without fat.

Therefore, the intake of most nutrients were higher in the diet without fat; as stated previously, this diet showed a higher dry matter intake, thus resulting in greater consumption of nutrients.

The crude protein and non-fibrous carbohydrates were higher in the absence of protected fat in the diet, regardless of the use of vitamin $E$, which can be explained by the higher dry matter intake in treatments without fat (Table 4). Similar results for crude protein were found by Urano et al. (2006), who observed average daily consumption of $183.7 \mathrm{~g} /$ day of crude protein in diets with fat. This average decreased with the increase of fat in the diet, which can be explained by lower consumption of dry matter.

Lambs of the treatments with protected fat consumed less non-fibrous carbohydrates than the others due to the lower level of this nutrient in the diets containing lipid inclusion (Table 4). Homem Junior (2008) also noted that consumption of non-fibrous carbohydrates was lower when there was fat added in the diet. In this sense, replacing carbohydrate sources for lipids, and keeping the energy level, the supply of carbohydrates, especially the nonstructural, eventually decreases, thereby decreasing their consumption.

The average intake of ether extract in diets with and without vitamin $\mathrm{E}$ was higher for diets with protected fat (Table 5). Haddad \& Younis (2004), evaluating the effects of addition of protected fat in the diet of lambs also found higher consumption of ether extract in diets containing protected fat. Urano et al. (2006) also noted that the use of ether extract was higher when there was addition of fat in the diet. Homem Junior (2008), studying the inclusion of lipids from sunflower seeds or from the protected fat in high concentrate diets for lambs, observed that the use of ether extract in the treatment with protected fat was higher than the diet with sunflower grain, and the latter, in turn, higher than the control, due to the ether extract content of the diet.

The consumption of organic matter and cell content (Table 5) in the absence of vitamin $\mathrm{E}$ in the diet were higher in diets without fat, and in general average the consumption was higher in diets without fat.

Confined lambs with $20-25 \mathrm{~kg}$, fed diets containing vitamin $\mathrm{E}$ and without protected fat, had higher gross energy consumption when compared with those receiving diets with vitamin E and containing protected fat (Table 6). This may be due, as already reported, to higher intake of dry matter in the absence of fat in the diet, and in this case, vitamin E ended up emphasizing the difference that was not observed when the same was not present in the diet.

Table 4 - Mean values of crude protein (CP) and non-fiber carbohydrates (NFC) of lambs, due to the use of protected fat in the $\operatorname{diet}^{1}$

\begin{tabular}{lcc}
\hline Variable & \multicolumn{2}{c}{ Protect fat } \\
\cline { 2 - 3 } & Absence & Presence \\
\hline Crude protein (kg/day) & $0.212 \mathrm{a}$ & $0.186 \mathrm{~b}$ \\
Non-fiber carbohydrates (kg/day) & $0.386 \mathrm{a}$ & $0.354 \mathrm{~b}$ \\
\hline${ }^{1}$ Means followed by different letters differ by the F test.
\end{tabular}


The initial weight range had a significant effect on the final weight and empty body weight. The use of protected fat in the diet influenced the weight of digestive content. The feed conversion had effect of the interaction between the confinement weight and the use of fat in the diet. For daily weight gain and total gain, the use of protected fat and vitamin $\mathrm{E}$ in the diet had no effect (Table 7). The coefficients of variation for feed efficiency and feed conversion were high, probably due to large differences of the lambs consumption, as a result of the restriction on their performance before the experiment started.
The daily weight gain, although not affected by the evaluated variables, was higher than the $200 \mathrm{~g}$ /day recommended by NRC (2007). Salinas et al. (2006) and Haddad \& Younis (2004), using protected fat in lambs’ diet, also found no significant effect on daily weight gain. Awawdeh et al. (2009), assessing lambs fed with fat sources, found greater weight gain when the source of lipid was added to the diet. Yakan \& Unal (2010) found a reduction in average daily gain for lambs slaughtered at higher weights. The use of protected fat in the diet did not influence the total weight gain of lambs. The same result was found by Jaeger et al. (2004) and Garcia et al. (2010),

Table 5 - Average consumption of ether extract, organic matter and cellular content depending on the unfolding of the interaction between the addition of vitamin $\mathrm{E}$ and protected fat in the diet of Santa Inês lambs ${ }^{1}$

\begin{tabular}{|c|c|c|c|c|}
\hline \multirow[t]{2}{*}{ Variable } & \multirow[t]{2}{*}{ Vitamin E } & \multicolumn{2}{|c|}{ Fat } & \multirow[t]{2}{*}{ Mean } \\
\hline & & Absence & Presence (4\%) & \\
\hline \multirow[t]{3}{*}{ Ether extract (kg/day) } & Absence & $0.034 \mathrm{Ba}$ & $0.065 \mathrm{Ab}$ & $0.050 \mathrm{a}$ \\
\hline & Presence & $0.031 \mathrm{Ba}$ & $0.077 \mathrm{Aa}$ & $0.054 \mathrm{a}$ \\
\hline & Mean & $0.033 \mathrm{~B}$ & $0.071 \mathrm{~A}$ & $C V=20.31$ \\
\hline \multirow[t]{3}{*}{ Organic matter (kg/day) } & Absence & $1.289 \mathrm{Aa}$ & $0.959 \mathrm{Ba}$ & $1.124 \mathrm{a}$ \\
\hline & Presence & $1.169 \mathrm{Aa}$ & $1.129 \mathrm{Aa}$ & $1.149 \mathrm{a}$ \\
\hline & Mean & $1.229 \mathrm{~A}$ & $1.044 \mathrm{~B}$ & $\mathrm{CV}=17.20 \%$ \\
\hline \multirow[t]{3}{*}{ Cellular content (kg/day) } & Absence & $0.014 \mathrm{Aa}$ & $0.008 \mathrm{Ba}$ & $0.011 \mathrm{a}$ \\
\hline & Presence & $0.012 \mathrm{Aa}$ & $0.011 \mathrm{Aa}$ & $0.012 \mathrm{a}$ \\
\hline & Mean & $0.013 \mathrm{~A}$ & $0.009 \mathrm{~B}$ & $\mathrm{CV}=32.05 \%$ \\
\hline
\end{tabular}

${ }^{1}$ Means followed by different letters, uppercase in rows and lowercase in columns, differ by $\mathrm{t}$ test.

$\mathrm{CV}=$ coefficient of variation.

Table 6 - Average intake in Mcal/kg of gross energy according to the unfolding of the interaction between the initial confinement weight, the presence of protected fat and vitamin $\mathrm{E}$ in the diet ${ }^{1}$

\begin{tabular}{|c|c|c|c|}
\hline \multirow[t]{2}{*}{ Fat } & \multirow[t]{2}{*}{ Vitamin E } & \multicolumn{2}{|c|}{ Weight } \\
\hline & & $30-35 \mathrm{~kg}$ & $20-25 \mathrm{~kg}$ \\
\hline \multirow[t]{2}{*}{ Absence } & Absence & $0.062 \mathrm{AaA}$ & $0.062 \mathrm{AaA}$ \\
\hline & Presence $(0.05 \%)$ & 0.049Ааа & 0.068 Ааа \\
\hline \multirow[t]{2}{*}{ Presence (4\%) } & Absence & 0.049AаA & $0.050 \mathrm{AaA}$ \\
\hline & Presence $(0.05 \%)$ & 0.058 Aаa & 0.049Aab \\
\hline
\end{tabular}

${ }^{1}$ Means followed by different letters differ by t test. In the rows, uppercase letters differentiate weight ranges; in columns, lowercase letters differentiate the addition of vitamin in the total diet in each addition of fat in the total diet; bold lowercase letters differentiate the addition of fat in the presence of vitamin E; and bold uppercase letters differentiate the added fat in the absence of vitamin $\mathrm{E}$.

Table 7 - Mean values of performance parameters, $\mathrm{F}$ probability for each source of variation, $\mathrm{W}=$ initial confinement weight, $\mathrm{F}=$ presence or absence of protected fat, $\mathrm{V}=$ presence or absence of vitamin $\mathrm{E}$, their interactions and coefficient of variation (CV)

\begin{tabular}{|c|c|c|c|c|c|c|c|c|c|}
\hline \multirow[t]{3}{*}{ Variable } & \multirow[t]{3}{*}{ Mean } & \multicolumn{7}{|c|}{ F Probability } & \multirow[t]{3}{*}{$\mathrm{CV} \%$} \\
\hline & & \multirow[t]{2}{*}{ W } & \multirow[t]{2}{*}{$\mathrm{F}$} & \multirow[t]{2}{*}{ V } & \multicolumn{4}{|c|}{ Interactions } & \\
\hline & & & & & $\mathrm{W} \times \mathrm{F}$ & $\mathrm{W} \times \mathrm{V}$ & $\mathrm{F} \times \mathrm{V}$ & $\mathrm{W} \times \mathrm{F} \times \mathrm{V}$ & \\
\hline FW (kg) & 49.591 & $<.0001^{* *}$ & 0.812 & 0.167 & 0.399 & 0.581 & 0.746 & 0.415 & 7.91 \\
\hline TWG (kg) & 21.751 & 0.359 & 0.924 & 0.796 & 0.544 & 0.553 & 0.533 & 0.836 & 21.20 \\
\hline ADG (kg/day) & 0.259 & 0.248 & 0.903 & 0.744 & 0.443 & 0.454 & 0.431 & 0.794 & 16.74 \\
\hline EBW (kg) & 42.222 & $<.0001 * *$ & 0.688 & 0.206 & 0.311 & 0.625 & 0.945 & 0.520 & 9.72 \\
\hline DC (kg) & 7.369 & 0.475 & $0.011^{* *}$ & 0.792 & 0.369 & 0.867 & 0.307 & 0.554 & 7.37 \\
\hline $\mathrm{FE}$ & 0.23 & 0.410 & 0.100 & 0.985 & 0.108 & 0.894 & 0.400 & 0.356 & 30.20 \\
\hline FC & 4.74 & 0.342 & 0.103 & 0.939 & $0.035 *$ & 0.998 & 0.384 & 0.400 & 26.32 \\
\hline
\end{tabular}

FW = final weight $(\mathrm{kg})$; TWG = total weight gain $(\mathrm{kg}) ; \mathrm{ADG}=$ average daily gain $(\mathrm{kg} /$ day); EBW = empty body weight $(\mathrm{kg})$; DC = digestive content $(\mathrm{kg})$; FE = feed efficiency; $\mathrm{FC}=$ feed conversion.

*significant at $\mathrm{P}<0.05, * *$ significant at $\mathrm{P}<0.01$. 
who included a source of fat in the diet. The non- influence of protected fat on weight gain is probably due to the fact that part of the fat source is inactive in the rumen, and probably what was fermented in this compartment was not enough to negatively influence the food degradation so it could affect animal performance.

The use of vitamin $\mathrm{E}$ in the diet did not influence performance characteristics. The vitamin $\mathrm{E}$ in this study was already present in the premix composition, ensuring the requirements for this category; with the extra supplementation a better performance on diets containing lipid source was expected. This is because, probably, the use of vitamin E may have been influenced by other dietary components such as unsaturated fatty acids provided by the use of protected fat.

Wulf et al. (1995), adding the same amount of vitamin $\mathrm{E}$ used in the diet of this study (500 mg vitamin E/head daily) and $1000 \mathrm{mg}$ vitamin E/head daily, had significant effect on total weight gain. Macit et al. (2003), supplementing $45 \mathrm{mg} /$ day of vitamin $\mathrm{E}$ observed an improvement of $6.7 \%$ increase in daily weight gain and $8.8 \%$ in feed conversion efficiency.

The final weight and empty body weight were higher for the confined animals of 30-35 kg body weight (Table 8), which was already expected, since these animals started the experiment heavier, and in the experimental course the total weight gain and the daily gain were similar for the two weight ranges (Table 7). Bueno et al. (2000), evaluating

Table 8 - Mean values for final weight, empty body weight and digestive contents of lambs finished with protected fat and vitamin $\mathrm{E}$ in different experimental weights ${ }^{1}$

\begin{tabular}{lcc}
\hline & \multicolumn{2}{c}{ Experimental } \\
\cline { 2 - 3 } & $30-35 \mathrm{~kg}$ & $22-25 \mathrm{~kg}$ \\
\hline Final weight $(\mathrm{kg})$ & $55.086 \mathrm{a}$ & $44.092 \mathrm{~b}$ \\
Empty body weight $(\mathrm{kg})$ & $47.559 \mathrm{a}$ & $36.815 \mathrm{~b}$ \\
& \multicolumn{2}{c}{ Protected } \\
& Absence & Presence \\
Digestive contents $(\mathrm{kg})$ & $7.871 \mathrm{a}$ & $6.932 \mathrm{~b}$ \\
\hline
\end{tabular}

${ }^{1}$ Means followed by different letters differ by $\mathrm{F}$ test.
Suffolk lambs slaughtered at different weights and ages, and Motta et al. (2001) and Abdullah \& Qudsieh (2008), evaluating different slaughter weights of lambs, also found significant differences for these variables.

The average weight of digestive contents (Table 8) was higher in the absence of fat in the diet; this may be due to higher consumption of diets that did not contain protected fat. Homem Junior (2008), studying the inclusion of lipids, also found higher contents of the gastrointestinal tract of lambs that consumed the diet without fat addition. By providing protected fat, the amount of energy allowed the animal to ingest less food, thus providing less digestive content, even after the fasting period.

The feed conversion in the diet without fat was better for the heavier confined animals, as they consumed less dry matter for the same daily weight gain than the lighter animals (Table 9). For the confined lambs of 20-25 kg, the conversion was better in the presence of protected fat in the diet. This was due to lower dry matter intake because of higher energy density of the protected fat diets, also for the same daily weight gain. Instead, Homem Junior (2008) found no difference in feed conversion between treatments testing different sources of lipids in the diet.

Hot carcass weight, cold carcass weight and cold carcass yield had the effect of initial confinement weight (Table 10). Bueno et al. (2000) and Motta et al. (2001) also found a significant difference for hot and cold carcass weight when evaluating lambs slaughtered at different ages and weights. The use of vitamin $\mathrm{E}$ in the diet influenced the cold carcass weight. There was an interaction between the initial weight, the use of protected fat and vitamin $\mathrm{E}$ in the diet for hot carcass weight, and the hot and cold carcass yield.

Cold carcass weight was higher for the heavier confined animals. This was expected since during the experimental period the total weight gain was similar for the two weight ranges, and adding this gain to the greater weight resulted in heavier animals with heavier carcass (Table 11). Bueno et al. (2000), evaluating Suffolk lambs slaughtered at different ages and weights found significant differences for the weight of hot and cold carcass.

Table 9 - Means of feed conversion due to the unfolding of the interaction between experimental weight and the presence of protected fat in the diet ${ }^{1}$

\begin{tabular}{lcccc}
\hline Variable & Weight & \multicolumn{2}{c}{ Fat } & \multirow{2}{*}{ Mean } \\
\cline { 3 - 4 } & & Absence & Presence (4\%) & \\
\hline Feed conversion & $30-35 \mathrm{~kg}$ & $4.487 \mathrm{Ab}$ & $4.725 \mathrm{Aa}$ & $4.606 \mathrm{a}$ \\
& $20-25 \mathrm{~kg}$ & $5.918 \mathrm{Aa}$ & $4.163 \mathrm{Ba}$ & $5.041 \mathrm{a}$ \\
& Mean & $5.203 \mathrm{~A}$ & $4.444 \mathrm{~A}$ & $\mathrm{CV}=26.32 \%$ \\
\hline
\end{tabular}

${ }^{1}$ Means followed by different letters, uppercase in the rows and lowercase in the columns, differ by t test. 
Animals that received diets with addition of vitamin E had higher cold carcass weight. Probably the vitamin acted in the preservation of plasma membranes leading to less fluid loss by muscle cells. Macit et al. (2003), evaluating the effects of vitamin E supplementation ( $45 \mathrm{mg} /$ day) in lambs, found no significant effect of the addition of vitamin $\mathrm{E}$ on characteristics of slaughter and carcass.

Average hot carcass weight was higher for the confined animals with $30-35 \mathrm{~kg}$ when compared with the lighter animals for all experimental diets; a result of the fact that they were heavier animals at the end of experimental period (Table 12). According to Silva Sobrinho (2006), as the live weight at slaughter increases, the yield of the carcass and the weight also increase. In this weight range (30-35 kg), there were differences in the diets with fat addition with the addition of vitamin E; animals supplemented with vitamin E had higher hot carcass weights - these lambs might have had greater slaughter weight than the others, although the statistical analysis did not identify this difference.

In the diets without fat addition and with vitamin $\mathrm{E}$ supplementation, the lighter confined animals had the highest carcass yield; this was due to lower hot carcass weight of these animals in these conditions and lower

Table 10 - Mean values of weights and carcass yield, F probability for each source of variation, $\mathrm{W}=$ initial confinement weight, $\mathrm{F}=$ presence or absence of protected fat, $\mathrm{V}=$ presence or absence of vitamin $\mathrm{E}$, their interactions and coefficient of variation (CV)

\begin{tabular}{|c|c|c|c|c|c|c|c|c|c|}
\hline \multirow[t]{3}{*}{ Variable } & \multirow[t]{3}{*}{ Mean } & \multicolumn{7}{|c|}{ F Probability } & \multirow[t]{3}{*}{ CV \% } \\
\hline & & \multirow[t]{2}{*}{ W } & \multirow[t]{2}{*}{$\mathrm{F}$} & \multirow[t]{2}{*}{ V } & \multicolumn{4}{|c|}{ Interactions } & \\
\hline & & & & & $\mathrm{W} \times \mathrm{F}$ & $\mathrm{W} \times \mathrm{V}$ & $\mathrm{F} \times \mathrm{V}$ & $\mathrm{W} \times \mathrm{F} \times \mathrm{V}$ & \\
\hline HCW (kg) & 23.281 & $<.0001^{* *}$ & 0.369 & 0.100 & 0.882 & 0.997 & 0.774 & $0.017^{*}$ & 8.22 \\
\hline CCW (kg) & 23.360 & $<.0001^{* *}$ & 0.858 & $0.051 *$ & 0.762 & 0.688 & 0.616 & 0.061 & 7.99 \\
\hline HCY (\%) & 49.37 & 0.076 & 0.298 & 0.642 & 0.475 & 0.314 & 0.896 & $0.014^{*}$ & 5.54 \\
\hline CCY (\%) & 49.53 & $0.038^{*}$ & 0.971 & 0.178 & 0.507 & 0.542 & 0.820 & $0.015^{*}$ & 3.81 \\
\hline
\end{tabular}

$\mathrm{HCW}=$ hot carcass weight; CCW $=$ cold carcass weight, $\mathrm{HCY}=$ hot carcass yield, CCY $=$ cold carcass yield. * significant at $\mathrm{P}<0.05$, ** significant at $\mathrm{P}<0.01$.

Table 11 - Mean values for cold carcass weight as a function of initial weight and the addition of vitamin $\mathrm{E}$ in the diet ${ }^{1}$

\begin{tabular}{lccccc}
\hline Variable & \multicolumn{3}{c}{ Weight } & & \multicolumn{2}{c}{ Vitamin E } \\
\cline { 2 - 3 } \cline { 5 - 6 } & $30-35 \mathrm{~kg}$ & $20-25 \mathrm{~kg}$ & & Absence & Presence \\
\hline Cold carcass weight $(\mathrm{kg})$ & $26.417 \mathrm{a}$ & $20.465 \mathrm{~b}$ & & $22.731 \mathrm{~b}$ & $24.151 \mathrm{a}$ \\
\hline
\end{tabular}

${ }^{1}$ Means followed by different letters, differ by $\mathrm{F}$ test.

Table 12 - Means of hot carcass weight, hot carcass yield, cold carcass yield due to the unfolding of the interaction between initial confinement weigh, the presence of protected fat and vitamin $\mathrm{E}$ in the diet $^{1}$

\begin{tabular}{|c|c|c|c|}
\hline \multirow[t]{2}{*}{ Fat } & \multirow[t]{2}{*}{ Vitamin E } & \multicolumn{2}{|c|}{ Experimental weight } \\
\hline & & $30-35 \mathrm{~kg}$ & $20-25 \mathrm{~kg}$ \\
\hline & & \multicolumn{2}{|c|}{ Hot carcass weight (kg) } \\
\hline \multirow[t]{2}{*}{ Absence } & Absence & $27.132 \mathrm{AaA}$ & 19.299BaA \\
\hline & Presence $(0.05 \%)$ & $26.351 \mathrm{Aaa}$ & 22.022 Ваа \\
\hline \multirow[t]{3}{*}{ Presence (4\%) } & Absence & $24.456 \mathrm{AbA}$ & $20.328 \mathrm{BaA}$ \\
\hline & Presence $(0.05 \%)$ & $27.572 \mathrm{Aaа}$ & $19.941 \mathrm{Baа}$ \\
\hline & & \multicolumn{2}{|c|}{ Hot carcass yield (\%) } \\
\hline \multirow[t]{2}{*}{ Absence } & Absence & 51.154AaA & 48.455А аA \\
\hline & Presence $(0.05 \%)$ & $50.151 \mathrm{Baа}$ & 50.641Ааа \\
\hline \multirow[t]{3}{*}{ Presence (4\%) } & Absence & 48.357 AaA & 49.430AaA \\
\hline & Presence $(0.05 \%)$ & 52.292Ааа & 46.151Bab \\
\hline & & \multicolumn{2}{|c|}{ Cold carcass yield (\%) } \\
\hline \multirow[t]{2}{*}{ Absence } & Absence & 50.496АаA & 48.095AaA \\
\hline & Presence $(0.05 \%)$ & 49.914Ааа & 50.247Ааа \\
\hline \multirow[t]{2}{*}{ Presence (4\%) } & Absence & 48.996AbA & 49.246AаA \\
\hline & Presence $(0.05 \%)$ & 52.289Ааа & 48.134 Ваа \\
\hline
\end{tabular}

${ }^{1}$ Means followed by different letters differ by t test. In the rows, uppercase letters differentiate weight ranges; in columns: lowercase letters differentiate the addition of vitamin in the total diet in each addition of fat in the total diet; bold lowercase letters differentiate the addition of fat in the presence of vitamin E; and bold uppercase letters differentiate the added fat in the absence of vitamin $\mathrm{E}$. 
slaughter weight. In the diets with protected fat and vitamin $\mathrm{E}$, the highest yields belonged to confined animals with $30-35 \mathrm{~kg}$, conferring with the values of the hot carcass weight in these diets in relation to the slaughter weight of these animals. This result was possibly influenced by compensatory growth in lambs with $20-25 \mathrm{~kg}$ during the experimental period. In this condition there is a greater development of some organs and viscera (not carcass components), proportionally reducing hot carcass weight.

Cold carcass yield in lambs fed with protected fat and vitamin $\mathrm{E}$ was higher than for heavier confined lambs. In confined animals with 30-35 kg of live weight and fed with protected fat diets, the vitamin supplementation had an effect: the supplemented lambs showed higher yields; this can be explained by their higher hot carcass weight.

In research done by Jaeger et al. (2004) and Garcia et al. (2010), evaluating diets with or without protected fat, the authors found no significant difference in hot carcass weight and carcass yield. Homem Junior (2008) noted that the hot carcass yield was higher in the carcass of lambs consuming the protected fat diet (48.5\%) compared with the control diet (46.5\%); however, the cold carcass yield did not differ between treatments.

The initial confinement weight significantly influenced all measures of cold carcass, unlike the inclusion of protected fat and vitamin E in the diet (Table 13). Except for chest depth, the inclusion of fat source in the diet resulted in the same for Garcia et al. (2010) and Manso et al. (2009), who included fat sources in lambs diet and found no differences for these characteristics. Awawdeh et al. (2009) also found no differences for carcass measures, except for subcutaneous fat thickness, which increased with the use of fat source in the diet. Also Macit et al. (2003), supplementing lambs with vitamin E found no effect on the cold carcass measures.

As for thickness of subcutaneous fat, Borys et al. (2004), Jaeger et al. (2004) and Salinas et al. (2006) found no influence of the use of fat sources in lambs diet for this characteristic.

All cold carcass measures were higher for the confined animals with higher weight, since the lambs were larger and heavier at slaughter and with higher carcass weights (Table 14). The subcutaneous fat thickness was also higher in the heavier confined animals. In general, with increasing lambs weight, the fat content in the carcass also increases (Silva Sobrinho, 2006). In the final portion of the loin, the fat thickness was higher because the deposition of subcutaneous fat in the back (rump) was greater than in front, since the deposition begins at this body region (Berg \& Butterfield, 1976).

The mean measures of subcutaneous fat between the $12^{\text {th }}$ and $13^{\text {th }}$ ribs indicate that these carcasses may be considered on average fat (from 2 to $5 \mathrm{~mm}$ thick). For this fat layer to have a protective function during cooling, it should be at least $3 \mathrm{~mm}$ thick (Tonissi, 2009). In this case, the carcasses of the heavier animals would have greater protection. Yakan \& Unal (2010) found that subcutaneous fat thickness increased with increasing slaughter weight.

In studies carried out by Bueno et al. (2000) and Abdullah \& Qudsieh (2008) with lambs at different slaughter weights, the authors obtained a significant difference for those measures that showed a positive linear relationship with slaughter weight.

Table 13 - Mean values of objective carcass measures, F probability for each source of variation, $\mathrm{W}=$ initial confinement weight, $\mathrm{F}=$ presence or absence of protected fat, $\mathrm{V}=$ presence or absence of vitamin $\mathrm{E}$, their interactions and coefficient of variation (CV)

\begin{tabular}{|c|c|c|c|c|c|c|c|c|c|}
\hline \multirow[t]{3}{*}{ Variable } & \multirow[t]{3}{*}{ Mean } & \multicolumn{7}{|c|}{ F Probability } & \multirow[t]{2}{*}{$\mathrm{CV} \%$} \\
\hline & & \multirow[t]{2}{*}{ W } & \multirow[t]{2}{*}{ F } & \multirow[t]{2}{*}{$\mathrm{V}$} & \multicolumn{4}{|c|}{ Interactions } & \\
\hline & & & & & $\mathrm{W} \times \mathrm{F}$ & $\mathrm{W} \times \mathrm{V}$ & $\mathrm{F} \times \mathrm{V}$ & $\mathrm{W} \times \mathrm{F} \times \mathrm{V}$ & \\
\hline Chest depth (cm) & 33.222 & $0.013 * *$ & 0.600 & 0.560 & 0.336 & 0.448 & 0.961 & 0.157 & 19.1 \\
\hline Chest circumference $(\mathrm{cm})$ & 85.603 & $0.004 * *$ & 0.291 & 0.838 & 0.073 & 0.596 & 0.958 & 0.868 & 14.3 \\
\hline Hip circumference (cm) & 72.958 & $0.001 * *$ & 0.426 & 0.509 & 0.061 & 0.939 & 0.512 & 0.564 & 13.5 \\
\hline Carcass length $(\mathrm{cm})$ & 64.284 & $0.010 * *$ & 0.662 & 0.278 & 0.479 & 0.210 & 0.480 & 0.595 & 22.7 \\
\hline Rump width (cm) & 26.001 & $0.011 * *$ & 0.254 & 0.711 & 0.237 & 0.612 & 0.333 & 0.415 & 13.72 \\
\hline Leg length (cm) & 35.816 & $0.020 *$ & 0.378 & 0.596 & 0.089 & 0.919 & 0.360 & 0.259 & 19.16 \\
\hline Internal length $(\mathrm{cm})$ & 84.867 & $0.008 * *$ & 0.163 & 0.455 & 0.085 & 0.878 & 0.504 & 0.227 & 14.08 \\
\hline Leg width $(\mathrm{cm})$ & 13.782 & $0.016 *$ & 0.457 & 0.165 & 0.480 & 0.728 & 0.502 & 0.351 & 14.51 \\
\hline Subcutaneous fat (mm) & 2.795 & $0.043^{*}$ & 0.241 & 0.456 & 0.762 & 0.257 & 0.603 & 0.380 & $30.0 s$ \\
\hline Subcutaneous fat $2(\mathrm{~mm})^{1}$ & 3.598 & $0.034 *$ & 0.424 & 0.099 & 0.135 & 0.803 & 0.603 & 0.857 & 37.2 \\
\hline
\end{tabular}

${ }^{1}$ Subcutaneous fat of the final portion of the loin.

* significant at $\mathrm{P}<0.05$, ** significant at $\mathrm{P}<0.01$. 
Table 14 - Mean values of the objective measures of carcass as a function of initial confinement weight ${ }^{1}$

\begin{tabular}{|c|c|c|}
\hline \multirow[t]{2}{*}{ Variable } & \multicolumn{2}{|c|}{ Experimental weight } \\
\hline & $30-35 \mathrm{~kg}$ & $20-25 \mathrm{~kg}$ \\
\hline Chest depth (cm) & $36.080 \mathrm{a}$ & $29.600 b$ \\
\hline Chest circumference $(\mathrm{cm})$ & $92.384 \mathrm{a}$ & $77.653 \mathrm{~b}$ \\
\hline Hip circumference (cm) & $79.225 a$ & $65.494 b$ \\
\hline Carcass length (cm) & $71.584 \mathrm{a}$ & $56.094 b$ \\
\hline Rump width (cm) & $27.870 \mathrm{a}$ & $23.967 b$ \\
\hline Leg length (cm) & $38.629 a$ & $32.041 b$ \\
\hline Internal length $(\mathrm{cm})$ & $81.258 \mathrm{a}$ & $69.371 b$ \\
\hline Leg width $(\mathrm{cm})$ & $14.684 a$ & $12.688 \mathrm{~b}$ \\
\hline Subcutaneous fat (mm) & $3.167 \mathrm{a}$ & $2.451 b$ \\
\hline Subcutaneous fat $2(\mathrm{~mm})^{1}$ & $4.108 \mathrm{a}$ & $2.907 b$ \\
\hline
\end{tabular}

${ }^{1}$ Subcutaneous fat of the final portion of the loin. Means followed by different letters differ by $\mathrm{F}$ test.

\section{Conclusions}

The use of protected fat in the diet of Santa Ines lambs reduces the dry matter intake and increases the ether extract consumption. Supplementation with vitamin $\mathrm{E}$ in diets for lambs does not present relevant results for lamb performance and carcass yields. However, the use of protected fat along with vitamin $\mathrm{E}$ in heavier confined lambs improves the cold carcass yield. Confinement of lambs with different weights directly influences the carcass measures, regardless of the use of protected fat and/or vitamin $\mathrm{E}$ in the diet.

\section{References}

ABDULLAH, A.Y.; QUDSIEH, R.I. Carcass characteristics of Awassi ram lambs slaughtered at different weights. Livestock Science, v.117, n.2-3, p.165-175, 2008.

ARAUJO, D.B.; COOKE, R.F.; HANSEN, G.R. et al. Effects of rumen-protected polyunsaturated fatty acid supplementation on performance and physiological responses of growing cattle following transportation and feedlot entry. Journal of Animal Science, v.88, n.12, p.4120-4132, 2010.

AWAWDEH, M.S.; OBEIDAT, B.S.; ABDULLAH, A.Y. et al. Effects of yellow grease or soybean oil on performance, nutrient digestibility and carcass characteristics of finishing Awassi lambs. Animal Feed Science and Technology, v.153, n.3-4, p.216-227, 2009.

BERG, R.T.; BUTTERFIELD, R.M. New concepts of cattle growth. Sydney: Sydney University Press, 1976. 240p.

BORYS, B.; BORYS, A.; GASIOR, R. Effect of feeding rapeseed and linseed diets and their supplementation with vitamin $\mathrm{E}$ on health quality of lamb meat. Archiv Tierzucht, v.47, Special issue, p.189-197, 2004.

BUENO, M.S.; CUNHA, E.A.; SANTOS, L.E. et al. Características de carcaça de cordeiros Suffolk abatidos em diferentes idades. Revista Brasileira de Zootecnia, v.29, n.6, p.1803-1810, 2000 .

CARVALHO, S.R.S.T.; SIQUEIRA, R.S. Produção de ovinos em sistema de confinamento. In: SIMPÓSIO MINEIRO DE OVINOCULTURA: PRODUÇÃO DE CARNE NO CONTEXTO ATUAL, 1., 2001, Lavras. Anais... Lavras: UFLA, 2001. p.125-142.

EL KARIN, A.I.A.; OWENS, J.B.; WHITAKER, C.J. Measurement on slaughter weight, side weight, carcass joints and their association with composition of two types of sudan desert sheep. Journal of Agricultural Science, v.110, n.1, p.65-69, 1988 FISHER, A.V. New approaches to measuring fat in the carcasses of meat animals. In: REDUCING FAT IN MEAT ANIMALS, 1990, London. Proceedings... London: Elsevier Science Publishers, 1990. p.255-343.

FISHER, A.V.; BOER, H. The EAAP standard method of sheep carcass assessment. Carcass measurements ans dissection procedures. Report of the EAAP Workin Group on Carcass Evaluation, in cooperation with the CIHEAM Instituto Agronomico Mediterraneo of Zaragoza and the CEC Directorate General for Agruculture in Brussels. Livestock Production Science, v.38, n.2, p.149-159, 1994.

FURUSHO-GARCIA, I.F.; ALMEIDA, A.K.; COSTA, T.I.R. et al. Carcass characteristics and cuts of Santa Inês lambs fed different roughage proportions and fat source. Revista Brasileira de Zootecnia, v.39, n.6, p.1322-1327, 2010.

GARCIA, I.F.F.; ALMEIDA, A.K.; COSTA, T.I.R. et al. Carcass characteristics and cuts of Santa Inês lambs fed different roughage proportions and fat source. Revista Brasileira de Zootecnia, v.39, n.6, p.1322-1327, 2010.

GERASSEV, L.C.; PEREZ, J.R.O.; CARVALHO, P.A. et al. Efeitos da restrição pré e pós natal sobre o crescimento e o desempenho de cordeiros Santa Inês do desmame ao abate. Revista Brasileira de Zootecnia, v.35, n.1, p.237-244, 2006.

HADDAD, S.G.; YOUNIS, H.M. The effect of adding ruminally protected fat in fattening diets on nutrient intake, digestibility and growth performance of Awassi lambs. Animal Feed Science and Technology, v.113, n.1, p.61-69, 2004.

HOMEM JUNIOR, A.C.H. Grãos de girassol ou gordura protegida na dieta com alto concentrado e o ganho compensatório para cordeiros confinados. 2008. 89f. Dissertação (Mestrado em Zootecnia) - Unesp, Jaboticabal.

JAEGER, S.M.P.L.; DUTRA, A.R.; PEREIRA, J.C. et al. Características de carcaça de bovinos de quatro grupos genéticos submetidos a dietas com ou sem adição e gordura protegida. Revista Brasileira de Zootecnia, v.33, n.6, p.1876-1887, 2004.

MACEDO, F.A.F.; SIQUEIRA, E.R.; MARTINS, E.N. et al. Carcass quality of Corriedale, Bergamacia x Corriedale, and Hampshire Down x corriedale Lambs, finished on pasture or dry-lot. Revista Brasileira de Zootecnia, v.29, p.1520-1527, 2000.

MACIT, M.; AKSAKAL, V.; EMSEN, E. et al. Effects of vitamin E supplementation on fattening performance, non-carcass components and retail cut percentages, and meat quality traits of Awassi lambs. Meat Science, v.64, n.1, p.1-6, 2003.

MANSO, T.; BODAS, R.; CASTRO, T. et al. Animal performance and fatty acid composition of lambs fed with different vegetable oils. Meat Science, v.83, n.3, p.511-516, 2009.

MCDOWELL, L.R.; WILLIAMS, S.N.; HIDIROGLOU, N. et al. Vitamin E supplementation for the ruminant. Animal Feed Science and Technology, v.60, n.3, p.273-296, 1996.

MOTTA, O.S.; PIRES, C.C.; SILVA, J.H.S. et al. Avaliação da carcaça de cordeiros da raça Texel sob diferentes métodos de alimentação e pesos de abate. Ciência Rural, v.31, n.6, p.1051-1056, 2001.

MULLER, M.; PRADO, I.N.; LOBO JÚNIOR, A.R. et al. Diferentes fontes de lipídeos sobre o desempenho e características da carcaça de novilhas de corte confinadas. Animal Science, v.27, n.1, p.131-137, 2005.

NATICIONAL RESEARCH COUNCIL - NRC. Nutrent requeriments of sheep. 1.ed. Washington, D.C.: NAS, 2007. 384p.

PEREZ, J.R.O. Perspectivas da ovinocultura nas regiões sudeste e centro-oeste do Brasil. In: SIMPÓSIO INTERNACIONAL SOBRE CAPRINOS E OVINOS DE CORTE, 2., 2003, João Pessoa. Anais... João Pessoa: EMEPA, 2003. v.1, p.243-262.

PILAR, R.C.; PÉREZ, J.R.O.; TEIXEIRA, J.C. et al. Desempenho de Cordeiros Merino Australiano e cruza Ile de France x Merino Australiano. Ciência Agrotécnica, Edição Especial, p.1652-1661, 2003. 
RIBEIRO, T.M. Características da carcaça e do lombo de cordeiros submetidos a diferentes sistemas de terminação. In: REUNIÃO ANUAL DA SOCIEDADE BRASILEIRA DE ZOOTECNIA, 42., 2005, Goiânia. Anais... Goiânia: Sociedade Brasileira de Zootecnia, 2005. (CD-ROM).

RYAN, W.J.; WILLIAM, I.H.; MOIR, R.J. Compensatory growth in sheep and cattle. I. Growth pattern and feed intake. Australian Journal of Agricultural Research, v.44, n.7, p.1609, 1993.

SALINAS, J.; RAMÍREZ, R.G.; DOMÍNGUEZ, M.M. et al. Effect of calcium soaps of tallow on growth performance and carcass characteristics of Pelibuey lambs. Small Ruminant Research, v.66, n.1, p.135-139, 2006.

SAMPAIO, A.A.M.; BRITO, R.M.; CARVALHO, R.M. Comparação de sistemas de avaliação de dietas para bovinos no modelo de produção intensiva de carne. Confinamento de tourinhos jovens. Revista Brasileira de Zootecnia, v.31, n.1, p.157-163, 2002.

SAS INSTITUTE. SAS - SOFTWARE: changes and enhancement through release 9,0. Cary: SAS Institute, 2004. (CD-ROM).

SILVA, D.J.; QUEIROZ, A.C. Análise de alimentos: métodos químicos e biológicos. 3.ed. Viçosa, MG: UFV, 2002. 235p.

SILVA SOBRINHO, A.G. Criação de ovinos. 3.ed. Jaboticabal: Funep, 2006. 302p.

SIQUEIRA, E.R.; SIMÕES, C.D.; FERNANDES, S. Efeito do sexo e do peso ao abate sobre a produção de carne de cordeiro. I. Velocidade de crescimento, caracteres quantitativos da carcaça,
pH da carne e resultado econômico. Revista Brasileira de Zootecnia, v.30, n.3, p.844-848, 2001.

TONISSI, R.H. Produção e qualidade em ovinos de corte. Jaboticabal: Funep, 2009. 167p.

URANO, F.S.; PIRES, A.V.; SUSIN, I. et al. Desempenho e características da carcaça de cordeiros confinados alimentados com grão de soja. Pesquisa Agropecuária Brasileira, v.41, n.10, p.1525-1530, 2006.

VAN SOEST, P.J. Nutritional ecology of the ruminant. 2.ed. New York: Cornell University Press, 1994. 476p.

VASCONCELOS, P.M.B. Guia prático do confinador. São Paulo: Nobel, 1993. 226p.

WOOD, J.D.; MACFIE, H.J.H.; POMERY, R.W. Carcass composition in four sheep breeds: The importance of breed and stage of maturity. Animal Production, v.30, n.1, p.135-152, 1980.

WOOD, J.D.; MACFIE, H.J.H. The significance of breed in the prediction of lamb carcass composition from fat thickness measurements. Animal Production, v.31, n.3, p.315-319, 1980.

WULF, D.M.; MORGAN, J.B.; SANDERS, S.K. et al. Effects of dietary supplementation of vitamin $\mathrm{E}$ on storage and case life properties of lamb retain cuts. Journal of Animal Science, v.73, p.399-405, 1995

YAKAN, A.; UNAL, N. Meat production traits of a new sheep breed called Bafra in Turkey 1. Fattening, slaughter, and carcass characteristics of lambs. Tropical Animal Health and Production, v.42, n.4, p.751-759, 2010. 